\title{
Populations of Spore-forming Bacteria in an Acid Forest Soil, with Special Reference to Bacillus subtilis
}

\author{
By A. SIALA,* I. R. HILL† AND T. R. G. GRAY \\ Hartley Botanical Laboratories, University of Liverpool, P.O. Box I47, \\ Liverpool L69 $3 B X$
}

(Received 7 August 1973; revised 22 September 1973)

\section{SUMMARY}

The distribution of Bacillus subtilis in a pine-forest soil has been investigated by using the fluorescent-antibody technique and dilution plating. In the acid, mineral horizon of the soil, the organism occurred mainly in the vegetative condition, while in the alkaline, mineral horizon it was mostly present as spores. Within these soil horizons, the bulk of the vegetative bacteria was found on organic matter particles, but of those found on mineral particle surfaces, almost all were on cryptocrystalline quartz particles with iron oxide inclusions.

\section{INTRODUCTION}

Studies on the ecology of endospore-forming bacilli in soil have been concerned mostly with their occurrence and distribution within soil profiles (Holding, Franklin \& Watling, I965; Jensen, I963; Mishustin \& Mirsoeva, I968; Topping, I937; 1938; Vavulo \& Karbanovich, 1965). They have been shown to form a large percentage of the bacterial flora developing on dilution plates made from many soils, especially forest soils (Goodfellow, Hill \& Gray, 1965), but they are rare in low temperature soils (Baker \& Smith, 1972; Heal, Bailey \& Latter, 1967). Recently, Gray, Hissett \& Duxbury (1974) have shown that bacilli form a much higher percentage of the bacterial biomass than is generally realized because of the large weight of each individual.

Unfortunately, there is comparatively little information available on the occurrence of vegetative bacilli and spores in different situations and none on factors determining sporulation or germination and growth of bacilli in soil. Norris \& Wolf (I961) showed that it was possible to produce specific antisera to both the vegetative bacteria and spores of Bacillus subtilis. Later Hill \& Gray (1967) prepared specific fluorescent antisera with which they could identify these organisms and used them to demonstrate $B$. subtilis bacteria and spores on soil particles from an acid pine-forest soil. This paper describes an extension of this work in which the spore and vegetative bacterial populations of $B$. subtilis in different soil horizons have been examined, as well as their location in microhabitats.

\section{METHODS}

Sampling. Soil was obtained from the $H$ layer and the $A_{1}$ and $C$ horizons of a sand-dune soil planted with Pinus nigra (Goodfellow et al. 1968). The principal characteristics of these soils are: $H$ layer, largely organic residues from decomposed pine needles, $\mathrm{pH} 3.5 ; A_{1}$

\footnotetext{
* Present address: Faculty of Science, University of Libya, Tripoli, Libya.

$\uparrow$ Present address: ICI Plant Protection, Bracknell, Berkshire.
} 
horizon, mainly mineral soil with organic matter derived from leachates of decomposing

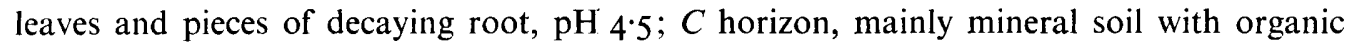
matter derived almost entirely from decaying roots and root exudates, $\mathrm{pH} 8 \cdot \mathrm{I}$.

A soil profile was exposed to a depth of $20 \mathrm{~cm}$ and five replicate samples were taken from the $H$ layer and $A_{1}$ and $C$ horizons in sterile $5 \times 2.5 \mathrm{~cm}$ glass tubes. These were used within $3 \mathrm{~h}$ of collection.

Isolation and counting of viable populations of bacteria. Each of the five replicate samples was thoroughly mixed and dilution plates prepared with peptone yeast extract agar by using the modified method described by Goodfellow et al. (I968), who showed that this medium gave consistently high counts for bacteria growing in this soil. To isolate and count bacterial spores, Io $\mathrm{ml}$ of a soil suspension were pasteurized by heating at $80{ }^{\circ} \mathrm{C}$ for $\mathrm{IO}$ min before preparation of the dilution series. To isolate and count Bacillus subtilis originating from either spores or vegetative forms, dilution plates were prepared by the methods already referred to, except that $0.1 \mathrm{ml}$ of each dilution was spread on the surface of dried agar plates. After incubation at $25^{\circ} \mathrm{C}$ for I week, colony prints were transferred to glass discs (diam, $85 \mathrm{~mm}$ ) by means of the replica plating technique (Lederberg \& Lederberg, I952). These were air dried, heat fixed and stained for $45 \mathrm{~min}$ with a fluorescent antibody preparation made from the ' $O$ ' antiserum to $B$. subtilis (Unger \& Wagner, 1965; Hill \& Gray, 1967). The stained colonies were washed with phosphate buffered saline $(\mathrm{pH} 7 \cdot 2)$ and deionized water. The glass plates were dried, backed with black paper and illuminated with u.v. light from the side, when $B$. subtilis colonies fluoresced bright green while other colonies were non-fluorescent.

Fluorescing colonies were counted on discs prepared from unheated and pasteurized suspensions and the results compared with counts made on the original plates from which the replicas had been prepared.

Identification of spore-forming bacteria. Isolates of spore-forming bacteria were identified by using the criteria of Smith, Gordon \& Clark (1952) and Wolf \& Barker (1968).

Fluorescent antisera were also used to identify vegetative forms of Bacillus subtilis on soil particles (Hill \& Gray, 1967). The soil particles were identified by their characteristic morphology and colour under the microscope when irradiated with u.v. and white light (Hill, 1967; Grant, 1962). The no. of bacteria/ $\mathrm{mm}^{2}$ of particle surface was determined. Bacteria masked by thick organic coatings or present inside organic particles could not be detected.

\section{RESULTS}

\section{Numbers of spore-forming bacteria in soil}

The populations of bacteria developing on peptone-yeast extract agar were compared with the populations of bacteria present as spores in four soil profiles. The highest numbers of bacteria were found in the organic $H$ layer and the lowest numbers in the mineral $A_{1}$ horizon (Table I). However, the percentage of these bacteria present as spores in the soil was much higher in the $A_{1}$ horizon ( $46 \%$ ) than in either of the other two horizons.

\section{Types of spore-forming bacteria}

Colonies on the isolation plates were selected at random and subcultured, purified and identified. Table 2 shows the principal species of Bacillus found. Bacillus circulans was the most commonly isolated type but this may reflect the fact that this is a poorly defined species to which a number of different types are assigned. B. subtilis was the commonest of the welldefined species, forming a high percentage of the isolates in all horizons. B. polymyxa 
Table I. Number of bacteria/g oven dried soil (pasteurized and non-pasteurized) from the $H$ layer, $A_{1}$ and $C$ horizons of a pine forest soil

\begin{tabular}{|c|c|c|c|}
\hline \multirow[b]{2}{*}{ Horizon } & \multicolumn{2}{|c|}{ No. of bacteria $\left(\times 1 \mathrm{IO}^{-5}\right)^{*}$} & \multirow{2}{*}{$\begin{array}{l}\text { Percentage of bacteria } \\
\text { present as spores }\end{array}$} \\
\hline & Non-pasteurized & Pasteurized & \\
\hline $\begin{array}{l}H \\
A_{1} \\
C\end{array}$ & $\begin{array}{c}33.55(16.69) \\
6.08(3.37) \\
12.00(3.97)\end{array}$ & $\begin{array}{l}5.26(2.9 I) \\
2.80(1.88) \\
2.56(0.75)\end{array}$ & $\begin{array}{l}15 \cdot 7 \\
46 \cdot 0 \\
2 \mathrm{I} \cdot 3\end{array}$ \\
\hline & te & - & 213 \\
\hline
\end{tabular}

Table 2. Occurrence of Bacillus species in the forest soil

\begin{tabular}{lccc} 
& \multicolumn{3}{c}{ Bacillus spore population $(\%)$ in } \\
Species & $H$ layer & $A_{1}$ horizon & $C$ horizon \\
B. circulans & 46 & 38 & 36 \\
B. subtilis & 28 & 16 & 30 \\
B. cereus & 6 & 14 & 6 \\
B. licheniformis & 2 & 8 & 4 \\
B. polymyxa & 0 & 10 & 8 \\
B. sphaericus & 12 & 2 & 0 \\
B. megaterium & 2 & 2 & 8 \\
B. firmus & 2 & 4 & 6 \\
B. lentus & 2 & 2 & 2 \\
B. brevis & 0 & 4 & 0
\end{tabular}

was found in the mineral soils only and $B$. sphaericus almost always in the $H$ layer. $B$. brevis was found only in the $A_{1}$ horizon. The other species were found in all the horizons. In addition to the strains shown in the Table, thirteen isolates failed to sporulate, but morphological, physiological and serological properties suggested that eight were $B$. circulans, four B. subtilis and one B. polymyxa.

The percentage of Bacillus subtilis colonies arising from spores was lowest in the $A_{1}$ horizon ( $16 \%$ ) which contrasts with an earlier report by Goodfellow (I966) who found that B. subtilis comprised $54 \%$ of the spore-forming bacteria isolated from unheated suspensions of $A_{1}$ horizon soil. This discrepancy suggested that $B$. subtilis was present in the $A_{1}$ horizon principally as vegetative bacterium, and this possibility was then tested.

Bacillus subtilis populations in the mineral soils

Heated and unheated soil suspensions from the $A_{1}$ and $C$ horizons were plated on peptone-yeast extract agar and glass replica discs prepared. Staining the colonies with fluorescent antibody enabled counts of Bacillus subtilis colonies originating from vegetative bacteria and spores to be made on the same soil samples. The numbers of $B$. subtilis propagules were found to be almost the same in both horizons, though they formed a slightly higher percentage of the population in the $A_{1}$ horizon (Table 3). The population of $B$. subtilis consisted of both spores and vegetative bacteria, the majority of propagules in the $A_{1}$ horizon being vegetative bacteria $(67.5 \%)$ and in the $C$ horizon spores $(8 \mathrm{r} \%)$.

Distribution of Bacillus subtilis vegetative bacteria on mineral and organic soil particles

Soil samples from five profiles were stained with fluorescent antibody and about 40000 soil particles were examined in each sample. In two of the profiles no vegetative bacteria of 

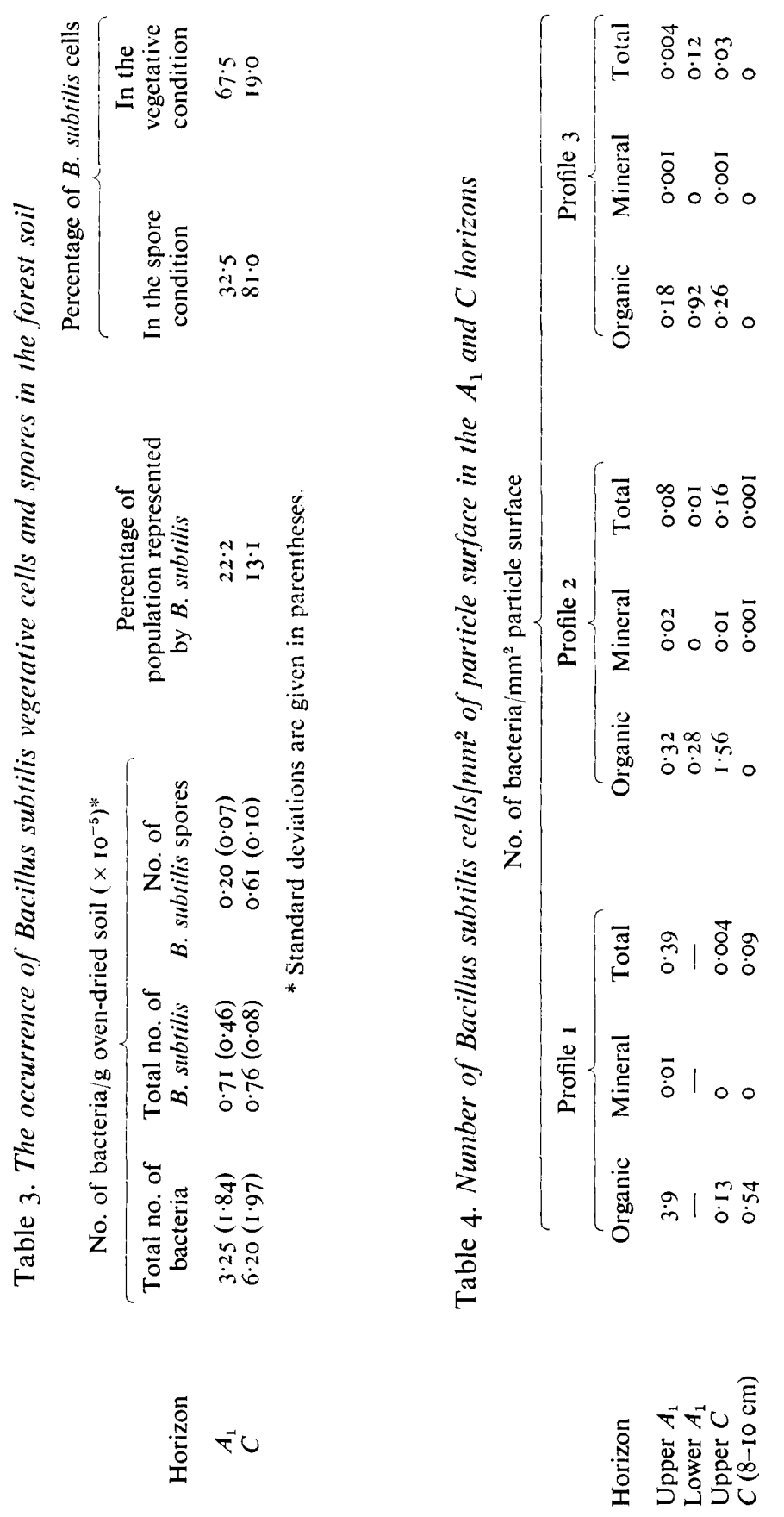
Table 5. Mean number of Bacillus subtilis cells/microcolony on mineral and organic particles in the $A_{1}$ and $C$ horizons

\begin{tabular}{|c|c|c|}
\hline \multirow[b]{2}{*}{ Horizon } & \multicolumn{2}{|c|}{ No. of cells microcolony } \\
\hline & Organic particles & Mineral particles \\
\hline $\begin{array}{l}A_{1} \\
C\end{array}$ & $\begin{array}{l}4 \cdot 6 \\
5 \cdot 0\end{array}$ & $\begin{array}{l}2.0 \\
2.0\end{array}$ \\
\hline
\end{tabular}

Table 6. Relative numbers of Bacillus subtilis cells on different types of mineral particle

Percentage of cells on mineral particles of different mineral types

$\begin{array}{lccc}\text { Horizon } & \text { Quartz } & \text { Cryptocrystalline quartz } & \text { Aluminosilicate } \\ \text { Upper } A_{1} & 0 & 100 & 0 \\ \text { Lower } A_{1} & 0 & 100 & 0 \\ \text { Upper } C & 0 & 100 & 0 \\ C(8-10 \mathrm{~cm}) & 10.7 & 89.3 & 0\end{array}$

Bacillus subtilis were found, but in the other three they were quite common (Table 4). Clearly, the majority of $B$. subtilis bacteria was found on organic matter particles, despite the fact that mineral particles constituted $85 \%$ of the available surface area for colonization. In the $A_{1}$ horizon, up to $20 \%$ of the bacilli were found on mineral particles, but only up to $7.5 \%$ were found in the $C$ horizon. The bacteria on organic particles occurred in larger colonies than those on mineral particles, with an average of five bacteria per colony (Table 5). Single bacteria were commoner on mineral particles, but on average there were two per colony. The size of the individual bacillus on organic particles was also larger (Hill \& Gray, 1967).

\section{Distribution of bacteria on mineral particles}

Several types of mineral particles were found in the soil, including cryptocrystalline quartz with iron oxide inclusions, cordierite, calcite, calcite with iron oxide inclusions, quartz and aluminosilicate. Examination of five samples of 10000 particles from each horizon showed that Bacillus subtilis was practically restricted to cryptocrystalline quartz particles with iron oxide inclusions (Table 6), even though these particles constituted only 5 to $6 \%$ of the total available mineral surface. $B$. subtilis vegetative forms must be preferentially stimulated by these particles or be preferentially ionically attracted.

\section{Distribution of bacilli on organic particles}

Different types of organic particles were removed from $5 \mathrm{~kg}$ samples of soil under aseptic conditions and transferred to sterile containers. Large numbers of these particles were stained and the density of colonization determined. Bacillus subtilis was found on all substrates of plant origin but could not be found on the remains of fungi or soil animals (Table 7). Very few bacilli were found on living roots or on living mycorrhizal rootlets, but larger numbers were found on dead roots and on unidentifiable organic fragments. The number of pieces of fungal hyphae examined was small and the presence or absence of fungal hyphae on the other opaque organic particles could not be determined. 
Table 7. Density of colonization of Bacillus subtilis cells on different types of organic particle

\begin{tabular}{|c|c|c|}
\hline \multirow[b]{2}{*}{ Organic particle type } & \multicolumn{2}{|c|}{$\begin{array}{c}\text { No. of cells } \mathrm{mm}^{2} \text { particle } \\
\text { surface }\end{array}$} \\
\hline & $A_{1}$ horizon & $C$ horizon \\
\hline \multicolumn{3}{|l|}{ Pine branches } \\
\hline Cortex & $12 \cdot 5$ & 0.5 \\
\hline Stele & $13 \cdot 1$ & 0.5 \\
\hline \multicolumn{3}{|l|}{ Pine roots } \\
\hline Living & 0.02 & 0.007 \\
\hline \multicolumn{3}{|l|}{ Dead } \\
\hline Cortex & $4 \cdot I$ & $2 \cdot 4$ \\
\hline Stele & $6 \cdot 3$ & $1 \cdot 6$ \\
\hline \multicolumn{3}{|l|}{ Mycorrhizal rootlets } \\
\hline Living & 0.06 & 0.08 \\
\hline Dead & 0.9 & 0.6 \\
\hline Detached and dead & 0.3 & 0.3 \\
\hline Charcoal & 0.003 & 0.07 \\
\hline Organic matter/hyphal aggregates & $2 \cdot 7$ & $3 \cdot 0$ \\
\hline Fungal hyphae & 0 & 0 \\
\hline Sclerotia & 0 & o \\
\hline Insect exoskeletons & 0 & 0 \\
\hline Molluse shells & 0 & 0 \\
\hline \multicolumn{3}{|l|}{ Resin aggregates } \\
\hline $\mathrm{HCl}$ soluble, crumbly & $0 \cdot 1$ & 0.1 \\
\hline $\mathrm{HCl}$ insoluble, hard & 0.02 & $0 \cdot I$ \\
\hline Unidentifiable & $3 \cdot 6$ & $0 \cdot 6$ \\
\hline
\end{tabular}

\section{DISCUSSION}

The distribution of Bacillus subtilis in the forest soil examined seems unusual. Unlike the total population of endospore-forming bacteria, this species was present mostly as vegetative bacilli in the acid $A_{1}$ horizon soil and mostly as spores in the alkaline $C$ horizon. A comparison of these two soils made solely on the basis of counts from pasteurized soil suspensions might give a misleading impression. Furthermore, the belief held by earlier workers (Conn, 1916) that bacilli are usually in the spore condition in soil requires modification. The regular addition of organic matter through leaf fall or root growth might allow vegetative proliferation.

It has previously been shown that bacterial endospores are resistant to low $\mathrm{pH}$ (Roberts \& Hitchins, I969). The assumption has often been made that it is this feature which allows endospore-forming bacteria to persist in acid soils because Bacillus subtilis, when maintained in the laboratory, will only grow at $\mathrm{pH}$ values above 5.0 . The presence of vegetative bacilli in acid soils suggests that they have different $\mathrm{pH}$ requirements for growth or that they grow in micro-environments with a higher $\mathrm{pH}$. The growth of other bacteria, e.g. Streptomyces (Williams \& Mayfield, 197I) and Arthrobacter (Lowe \& Gray, 1973) in artificial micro-sites of high $\mathrm{pH}$ has already been described. The relatively low numbers of vegetative bacilli in the alkaline $C$ horizon is more difficult to explain but could be because of alkaline toxicity or lack of nutrients for growth.

Investigations of the micro-environments in the soil showed that Bacillus subtilis occurred in highly localized areas on a comparatively small number of particles. Unfortunately, the internal surface area of this sandy soil is large (Gray, Baxby, Hill \& Goodfellow, I968) and so accurate investigation of the distribution of one species of bacterium is difficult, 
especially since environmental characteristics cannot be measured at surface micro-sites. A more promising approach would be to introduce bacteria into soil on an easily recoverable substratum and follow their growth or disappearance, and to use the fluorescentantibody technique to identify them. Their interaction with other living organisms could be established in relatively natural conditions. The results of such a study are reported by Siala \& Gray (I974) who have shown that Bacillus growth and spore germination are related to the growth of soil fungi.

We thank the Agricultural Research Council and the Libyan Government for grants enabling this work to be done. We also thank Dr M. P. Atherton, Geology Department, Liverpool University, for help with the petrographic analysis.

\section{REFERENCES}

BAKER, J. H. \& SMITH, D. G. (1972). The bacteria in an antarctic peat. Journal of Applied Bacteriology 35, $589-596$.

ConN, H. J. (1916). Are spore-forming bacteria of any significance in soil under normal conditions? Technical Bulletin of the New York State Agricultural Experiment Station 51, 187-195.

Goodfellow, M. (1966). The classification of bacteria in pine wood soil. Ph.D. thesis, University of Liverpool.

Goodfellow, M., Hill, I. R. \& Gray, T. R. G. (1968). Bacteria in a pine forest soil. In The Ecology of Soil Bacteria, pp. 500-515. Edited by T. R. G. Gray and D. Parkinson. Liverpool University Press.

Grant, J. (1962). Application of fluorescence analysis in sedimentary petrography. In Sedimentary Petrography, pp. 433-462. Edited by H. B. Milner, A. M. Ward and F. Higham. London: Allen and Unwin.

Gray, T. R. G., Baxby, P., Hill, I. R. \& Goodfellow, M. (1968). Direct observation of bacteria in soil. In The Ecology of Soil Bacteria, pp. 17I-192. Edited by T. R. G. Gray and D. Parkinson. Liverpool University Press.

Gray, T. R. G., Hissett, R. \& Duxbury, T. (1974). Bacterial populations of litter and soil in a deciduous woodland. II. Numbers, biomass and growth rates. Revue d'écologie et de biologie du sol (in the Press).

Heal, O. W., Bailey, A. D. \& LatTer, P. M. (1967). Bacteria, fungi and protozoa in Signy Island soils compared with those from a temperate moorland. Philosophical Transaction of the Royal Society B 252, I9I-I 97 .

HILL, I. R. (1967). Application of the fluorescent antibody technique to an ecological study of bacilli in soil. Ph.D. thesis, University of Liverpool.

Hill, I. R. \& GRAY, T. R. G. (1967). Application of the fluorescent antibody technique to an ecological study of bacteria in soil. Journal of Bacteriology 93, 1888-1896.

Holding, A. J., Franklin, D. A. \& Watling, R. (1965). The microflora of peat-podzol transitions. Journal of Soil Sciences 16, 44-59.

Jensen, V. (I963). Studies on the microflora of Danish beech forest soils. III. Properties and composition of the bacterial flora. Zentralblatt für Bakteriologie und Parasitenkunde (Abteilung II) Ir6, 593-6I I.

LeDerberg, J. \& LeDerberG, E. M. (I952). Replica plating and indirect selection of bacterial mutants. Journal of Bacteriology 63, 399-406.

Lowe, W. E. \& Gray, T. R. G. (1973). Ecological studies on coccoid bacteria in a pine forest soil. II. Growth of bacteria introduced into soil. Soil Biology and Biochemistry 5, 449-462.

Mishustin, E. N. \& Mirsoeva, V. A. (1968). Spore-forming bacteria in the soils of the USSR. In The Ecology of Soil Bacteria, pp. 458-473. Edited by T. R. G. Gray and D. Parkinson. Liverpool University Press.

NoRris, J. R. \& Wolf, J. (I96I). A study of antigens of the aerobic spore-forming bacteria. Journal of Applied Bacteriology 24, 42-56.

Roberts, T. A. \& Hitchins, A. D. (I969). Resistance of spores. In The Bacterial Spore, pp. 611-670. Edited by G. W. Gould and A. Hurst. London and New York: Academic Press.

Siala, A. \& GraY, T. R. G. (1974). Growth of Bacillus subtilis and spore germination in soil observed by a fluorescent-antibody technique. Journal of General Microbiology 8r, I9I-198.

Smith, N. R., Gordon, R. E. \& Clark, F. E. (1952). Aerobic Spore-forming Bacteria. U.S. Department of Agriculture Monograph I6. 
TopPING, L.E. (1937). The predominant microorganisms in soils. I. Description and classification of the organisms. Zentralblatt für Bakteriologie und Parasitenkunde (Abteilung II) 97, 289-304.

ToPPING, L. E. (1938). The predominant microorganisms in soils. II. The relative abundance of different types of organisms obtained by plating and the relation of plate to total counts. Zentralblatt fir Bakteriologie und Parasitenkunde (Abteilung II) 98, 193-201.

UNGER, H. \& WAGNER, M. (1965). A new method for quantitative exploitation of immunofluorescence and the possibility for its utilisation in rhizosphere research. In Plant-Microbes Relationships, pp. 31 I-315. Edited by J. Macura and V. Vancura. Prague: Czechoslovak Academy of Sciences.

Vavulo, F. P. \& Karbanovich, A. I. (1965). The occurrence of sporing forms of bacteria in different types of soils. Microbiology 34, $91-96$.

Williams, S. T. \& MAYFIELD, C. I. (197I). Studies on the ecology of actinomycetes in soil. III. The behaviour of neutrophilic streptomycetes in acid soils. Soil Biology and Biochemistry 3, 197-208.

Wolf, J. \& BARKer, A. N. (1968). The genus Bacillus: aids to the identification of its species. In Identification Methods for Microbiologists B, pp. 91-109. Edited by B. M. Gibbs and D. A. Shapton. London: Academic Press. 